\title{
Raja of Narayan: A colonised tiger or a nation?
}

\author{
Reyhan Özer Tanıyan
}

Niğde Ömer Halisdemir University, Turkey / Contact: rotaniyan@ pau.edu.tr

\begin{abstract}
Known best for his novels set in fictional town of Malgudi, R. K. Narayan, as a novelist of the colonized land, India, was affected by the culture of the colonial power. Narayan was also aware that the imposition of English education over an inferior society is a vital part of the colonial way of redesigning the colonized culture. Thus, he used the English, the language of the colonist, and literary forms to scrutinize colonialism and to illustrate the colonization process of the Indian society continually and gradually under erosion within colonial rule. He penned a synthesis between the Indian elements and the colonial ones in his novels, especially in Malgudi series. In A Tiger of Malgudi, R. K. Narayan creates an intriguing animal allegory within an innovative style of plot construction and characterization, which makes this novel distinctive in the series. In the novel, the fable-like narration is mingled with Hindu philosophy such as karma and reincarnation in order to draw attention to rich Indian heritage and Hinduism that are under the threat of degeneration by colonial culture. As a first person story-teller, the tiger Raja, narrates his life-story, shares his feelings and thoughts for human beings and reconsiders the events he has experienced. His narration bears the implications of a critique of colonial power and Hindu spirituality as well. Thus, in this article, the focus will be on the narration of the tiger which is a synthesis of colonial and Indian elements within the concepts of postcolonial theories; displacement, identity and power, and Hindu philosophy; karma, reincarnation, samsara and samādhi.

(C) 2020 The Literacy Trek \& the Authors - Published by The Literacy Trek APA Citation
\end{abstract}

Taniyan, R. O. (2020). Raja of Narayan: A colonised tiger or a nation?. The Literacy Trek, 6(2), 91103. https://doi.org/10.47216/literacytrek.700566

A prominent figure within literary world as an Indian originated writer, R. K. Narayan acts as a postcolonial nationalist writer who inspired the Commonwealth Literatures movement in the 1960s (Riemenschneider, 2005, p. 164-228). His works are generally in association with the traditional, rural and local elements and his settings bear the characteristics of Indian villages. His most famous setting (of 14 
novels and over 100 short stories) is the fictional town of Malgudi. This town is a semi-agrarian, semi-urban settlement in South India and it has been transformed into a blend of town, country and city spanning five decades of Narayan's literary career. Without exception, Narayan's Malgudi as an Indian “microcosm” (Walsh, 1971, p. 166-67) gives clues about India, about the depiction of the Orient in general and also about the ideological adherents of colonial thought.

Of this series, in A Tiger For Malgudi (1983), Narayan illustrates an animal allegory within an intriguing plot construction and characterization that makes the novel distinctive in Malgudi series. Written as a fable by using a tiger as his main character, Narayan mocks mankind as selfish and egocentric beings who deny the possibility that "other creatures may also possess ego, values, outlook, and the ability to communicate, though they may be incapable of audible speech" (Narayan, 1984, p. 7). Moreover, by leading readers to observe the events through the tiger's eyes, Narayan also criticizes mankind, who "is all-important, that all else in creation exists only for his sport, amusement, comfort, or nourishment" (Narayan, 1984, p. 8). This criticism is made through the philosophical underpinnings of Hinduism and the inevitable effect of British Imperialism that are artistically interwoven.

At the centre of the novel, there is Raja as a reincarnated body; "only a tiger in appearance [...] a sensitive soul who understands life and its problems exactly as [humans] do [...] a gift from God" (Narayan, 1984, p. 151). As a nationalist, Narayan traces Raja's life ranging from forest to zoo within the frame of the Hindu concepts of dharma, which points, in essence, how an individual possesses particular abilities and functions in society, and karma, which determines that every action produces an effect manifested in a present lifetime or a future one (Chennakesavan, 1976, p. 195225), and samsara which is a concept closely associated with the belief that there is a continuous birth in various realms and forms such as human, animal, or other being (depending on karma). In other words, although one seems to be trapped within the predetermined cycle of dharma and karma chain, mankind has the chance of retaining wills and the capability of breaking the cycle of existence by using again free will. Therefore, this personified tiger chronicles his life as it comes an end in a zoo where he has been sent by Master, whom Raja and several human characters regard as a sadhu (renouncers living a life apart from - or on the edges of society - to focus on 
their own spiritual practice (Flood, 1996, p. 92). After being in the jungle, in a circus, on a movie set, and asleep in the office of a school's headmaster, Raja comes under Master's spell. Conditioned as much by Master's self-seeking, disingenuous "philosophy" unlike Captain's (his previous master) "wrong philosophy" (Narayan, 1984 , p. 84), the tiger's zoological and supposedly dharma like role is to make people, "particularly children, [...] happy" (Narayan, 1984, p. 152). As an anti-colonialist, Narayan shows the readers the other side of the story in which he tries to draw a picture of a colonised homeland that they avoid seeing by endowing Raja with a soul. He implies his nationalist and anti-colonial stance by voicing out a tiger. In this context, this study aims to discover the intentions of Narayan disguised in a tiger's voice. It will also be argued that with this voice, he criticizes the practices of the colonial minds, both of the colonizer and the colonized, by addressing to the authentic Indian practices that he believes as the only fact. Narayan starts the story first by addressing the readers. He stresses the hidden message behind the disguised persona of the tiger. Strictly related with the idea of samsara in Indian belief, he begins his life story with a sorrowfully accepted anger that not only acknowledges but criticizes his nation's nature.

You are not likely to understand that that I am different from the tiger next door, that I possess a soul within this forbidding exterior. I can think, analyse, judge, remember and do everything that you can do, perhaps with greater subtlety and sense. I lack only the faculty of speech. But if you could read my thoughts, you would be welcome to come in and listen to the story of my life. (Narayan, 1984, p. 11-12)

Narayan not only reflects the basic tenets of Hinduism in his story telling but constructs a quite subtle plot in which he makes a tiger the narrator whose nature is close to that of man. Raja, the tiger, tells his life story as the main narrator with its first person narration drawing elements from his memoir. He talks about his "early days as a cave-dweller and jungle beast" (Narayan, 1984, p. 12) and his cub-hood "frolicked on the sandy bank and in the cool stream, protected and fed by a mother" (ibid). His quest begins when his mother vanished one night: "I starved except when I could catch miserable creatures $[\ldots]$ and survived somehow. Not only survived, in course of time considered myself the Supreme Lord of the Jungle, afraid of no one, striking terror in others" (Narayan, 1984, p. 12-13). Raja defines his identity as a 
fierce predator of the jungle which is gifted with an intellect. His supremacy is being a spokesperson for the animal kingdom, one who dispels man's misconceptions about animals:

We the denizens of the jungle can communicate, without words, exactly as human beings do - we are capable of expressing to each other sympathy, warning, abuse, irony, insult, love and hatred exactly in the manner of human beings, but only when necessary, unlike human beings who talk all their waking hours, and even in sleep. (Narayan, 1984, p. 13)

The novel develops in three main parts each recounting a different period of Raja's life. In each part recounting a period of Raja's life, the aspects of the dharmakarma theme are expressed as well as the illustration of the colonial process. The first part covers Raja's jungle life, his fight with the female tiger, and their eventual coupling. When Raja's family is taken by hunters, he wants to take revenge and begins to hunt domestic animals of villages. From "King of the Forest" (Narayan, 1984 , p. 13) completely at home in the natural world, Raja turns into a caged animal as a result of taking the easy way. Through his own carelessness, he is trapped by Captain, an animal trainer and owner of the Grand Malgudi Circus, and thus begins the second part of the novel. In this part, Raja acts as a circus animal and a film star, with an only aim to keep his owner happy and his audience entertained. However, after getting angry when threatened by an electric cattle prod, Raja accidentally kills Captain and escapes terrorizing the village, although no one is ever actually in danger. The third part of the novel centres on Raja's period with the Master, a sadhu who saves the tiger from the villagers when he is kept at a school he jumped in. Raja becomes the Master's devoted student which learns much about his nature, his place and his relationship with his Creator. The novel ends with the Master leaving to attain samadhi and Raja entering a zoo to live out his remaining years.

Raja, the name of the tiger, refers to a monarch or princely ruler. It is a highly symbolic name as a tiger is known for its power and also is acknowledged as the king of the forest. This stress on power is in conjunction with other forms of power which seek domination. Cultural notions were exploited during the colonial process and "hegemonic ideologies are utilized to legitimize imperial regimes"; therefore, in India, "the Raja was represented as modernizing India, emphasizing the weak, 'backward' and disunited nature of Indian society and the superiority of British 
institutions and legal systems" (Cohn, 1996 p. 124). Thus, the interpretation or signification of the name have become blurred as a result of the different approaches of both sides. In traditional version, the name invokes a sublime meaning while it turns into a degrading one in newly imposed version. As asserted by Cohn, "the British had not only invaded and conquered India but $[\ldots]$ had invaded an epistemological space [and] reordered the nature of Indian knowledge" (1996, p. 53). This is exactly the situation of the tiger and its prototypical colonization process.

The first part of the novel centres on Raja's jungle life in which he hunts with no remorse for his actions: briefly a predator. As a representative Indian figure, he lives in his homeland happily unaware of an outer world till the arrival of the first invaders:

I had thought till now that our jungle home was impregnable and unapproachable for human beings. [...] Now human feet had strayed in and touched our ground, and that brought to my mind strange forebodings [...] They were too intoxicated to notice me. (Narayan, 1984, p. 21).

With the first threats of people to the life of Raja, Narayan makes a reference to colonial threats of colonial powers to Indian culture. Westerners, especially the British, colonized India for their own benefits and interests like the hunters of Malgudi who sell both the fur and lives of tigers for profit. Colonial practices did not only have a tremendous effect on cultural life of the colonized nation. These practices also had a dire impact upon the natural life and agricultural activities. "Conservation of the wild, linked to the European hunting and shooting craze that peaked in the 'high noon' of late imperialism, often crowded out and undermined indigenous hunting practices and thus adversely affected diets, and indigenous economic and social structures (Bush, 2006, p. 84). Also as it is recorded in history, "British 'factories' (trading posts) had been established on the coasts with Indian approval in the eighteenth century, in order to cope with the huge demand for chintzes (washable decorated fabric), indigo, saltpetre, rice and sugar cane" (Johnson, 2002, p. 24).

In the novel, this invasion for the sake of Indian goods is exemplified with the abduction scene of Raja's family. A group of man comes to the jungle and traps the wife and cubs of Raja. That group kills the tigress for its fur and sells the cubs to zoos or people who want to show their superiority. Before the arrival of the invading 
powers, neither Raja nor India has been aware of a world in which "[...] wildness, violence, and unthinking cruelty inflicted on weaker creatures" (Narayan, 1984, p. 13). This event lights the fuse of the second part of the novel in which Raja's family is exterminated by hunters. After they are taken, Raja tries to find them but he could not:

The air blowing in our direction brought some strange unfamiliar noises, [...] I felt disturbed and bewildered. No sign of the cubs or the mother. I let out a roar that should ring through the forest. [...] Normally when I called there would be an answer, but today there was none [...] (Narayan, 1984, p. 21).

After losing his whole family, there arises "a blind impossible anger" within him and he "just wanted to dash up, pounce upon every creature, bite and claw and destroy" (Narayan, 1984, p. 24) as a result of "an implacable enmity between native and invader" (Parry, 1987, p. 32). With burning anger inside, Raja goes to the town to find his family and soon realizes that hunting domestic animals is much easier than preying in the wild, hence, he begins to hunt villager's sheep from barns. This is actually his tragic flaw since this easy hunting or life style accustoms him to a readymade or a given life, simply dependency. Much after Raja grasps his assimilation from what he is by nature in regret: "Looking back, I feel that I should not have chosen the easy path-of raiding villages" (Narayan, 1984, p. 31). With a remorse of his wrong decision in giving up his own nature, Raja forgets who he is gradually and he transforms into a puppet performing in a circus for his patrons and film directors. This is the dharma/karma relationship and can also be related to the Indians. Like Raja, who is happy with the results of readymade food and a preorganized life before him, Indians at first are happy with the coming of British troops. British founded factories and created opportunities for Indians to earn money. They gave up their way of living and tried to adopt the life style of British residents in India who "sustained a lifestyle which emphasized superiority and power" (Bush, 2006, p. 69). Thus, Narayan through Raja implies what he believes: [we] "should not have chosen the easy path" (1984, p. 31).

Moreover, in contrast to the first part, the second part of his life places Raja in a completely unnatural environment. While he is roaming around the town by hunting the livestock of villagers, he is trapped by a circus manager called Captain. He is 
taken to circus area where he is going to live. This new place is not suitable for his life style and quite unfamiliar:

Suddenly all the twigs and foliage screening the cage were torn away and I saw through the bars a new world such as I could never have imagined in my life - a stretch of land with no trees or rocks or long grass or bamboo clusters or lantana bushes or other undergrowth, but bare and clean ground as far as I could see, ending in what I learnt was a big tent surrounded by smaller tents and shacks, the whole ground swarming with bipeds. I had no notion that the earth contained so many human creatures. Naturally they stared and gaped and talked. I tried to head my way out by pushing, and hurt myself in the attempt. (Narayan, 1984, p. 39- 40).

This transfer of Raja from his home to somewhere else is quite tragic. With such a forced transportation and relative enslavement, his "valid and active sense of self" will be "eroded by dislocation resulting from migration, the experience of enslavement, transportation, or 'voluntary' removal for indentured labour" (Ashcroft et al, 2009, p. 9). When examined from the postcolonial perspective, this dislocation or displacement of Raja results with an identity problem since he is forced to live in a place quite unfamiliar and far from his culture. Captain declares "We will teach this fellow every accomplishment in due course, $[\ldots]$ as they "drive him into the other cage, which is going to be his new home" (Narayan, 1984, p. 40). It means in colonial discourse, there will be an imposition of a new culture either consciously or unconsciously. The erosion of cultural identity, as Ashcroft puts forward, will be through dislocation or:

by cultural denigration, the conscious and unconscious oppression of the indigenous personality and culture by a supposedly superior racial or cultural model. The dialectic of place and displacement is always a feature of post-colonial societies whether these have been created by a process of settlement, intervention, or a mixture of the two (Ashcroft et al, 2009, p. 9).

Under the reign of Captain, Raja is educated against his nature. He is forced to jump through a burning frame, sit on a chair and even to drink milk with a goat from the same pot. These are the perfect examples to the creation of a new identity that Captain desires since "identity is only ever possible in the negation of any sense of originality or plenitude, through the principle of displacement and differentiation" (Bhabha, 1994, p. 118). With the negation of his original identity, Raja is "educated" 
into performing circus tricks and turning his back on his natural instincts (drinking milk with a goat). It is what "the special postcolonial crisis of identity comes into being; the concern with the development or recovery of an effective identifying relationship between self and place" (Ashcroft et al, 2009, p. 8-9). Raja, ironically, begins to adopt his new self and place, eating without hunting, sleeping without any disturbance. In brief, living an easy life in an exchange of his authenticity makes him happy.

I was happy to find there pieces of meat and a trough of water. My first piece of education. I understood the business now and the routine to be followed. Every day at the same hour they would drive me into a wheeled cage and draw it to the larger enclosure and let me out, where Captain waited with chair and whip. The moment the door was raised and the whip was flourished, I started running round and round. Then back to the cage, to be wheeled off to my home, which I found cleaned and washed and with food kept for me. That was very welcome. I'd have nothing more to do for the rest of the day. Life was not so bad after all. (Narayan, 1984, p. 46)

Besides adopting the new place and his new self, Raja not only accepts the given forms but also internalizes the norms of the superior power. It is highly necessary to point mimicry in this context, which expresses the 'epic' project of the civilizing mission to transform the colonized culture by making it copy or 'repeat' the colonizer's culture (Bhabha, 1984, p. 125-133). Through this process, Raja begins to admire even the tyranny of Captain and tries to do his best to make him happy.

I began to respect him for his capabilities. I began to admire him - a sort of worshipful attitude was developing in me. I had thought in the jungle that I was supreme. Now that was gone. I was a defeated king, and Captain was the unquestioned suzerain. After all, what he expected of me seemed so simple instead of understanding it, I allowed myself to be beaten, and suffered through ignorance. And running around the enclosure was quite beneficial for one cooped up in a cage all day. [...] My only aim now was to please Captain, and when I did that I got the reward, pieces of meat and water and undisturbed sleep in my cage. (Narayan, 1984, p. 46-48)

This admiration, or even worship, of Raja reminds Macaulay's essay on Warren Hastings, which explains the principles of government espoused by the East India Company in the following manner. He says, "Be the father and the oppressor of the people; be just and unjust, moderate and rapacious" (1903, p. 85-86). Captain as an oppressor is rapacious at his education system but for Raja, he is so moderate. 
When Raja pleases him, he gives reward but when Raja could not succeed in accomplishing the commands of Captain, he punishes him by keeping him hungry. However, Raja praises his power. In fact, Narayan implies the general fact that "the extension of British power was dependent on the willing participation of Indians, either as allies, or by those employed as revenue collectors, merchants and sepoys" (Johnson, 2002, p. 24). The willing participation here is the eagerness of Raja to get praise or a good word from Captain, thus he tries to adopt Captain's values. He pleases the captain by obeying him without any hesitation and adopts Captain's way of life as his. He turns into a copy of Captain's life, yet a blurred one.

When colonial discourse encourages the colonial subject to 'mimic' the colonizer, by adopting the colonizer's cultural habits, assumptions, institutions and values, the result is never a simple reproduction of those traits. Rather, the result is a 'blurred copy' of the colonizer that can be quite threatening. (Ashcroft et al, 2007, p. 124125)

This "blurred" copy is sometimes a threatening quality to colonisers and their images. In this case, the threatening quality of blurred copy shows itself when Raja is at show in circus with a goat.

Normally when Captain fixed his look on me, I'd be nearly paralyzed, and obey. But now, suddenly he had to look away, [...] I chose this moment to shoot forward and nip off the goat's head. There were shouts and cries and confusion from a section nearby for a minute, and Captain whipped me hard, picked up his chair, hit me with it, and drove me back to my cage. The goat was finished. (Narayan, 1984, p. 65).

This event is exactly "colonized subject's peculiar awareness of cultural, political, and social inauthenticity, of being ideologically constructed and fixed in representation". (Flood, 1996, p. 130). For such situations, Bhabha differentiates mimicry and inauthenticity by calling it as menace to the mimicry; "A sudden awareness of inauthenticity, of authority's constructed and assumed guise, is the menace of mimicry" (Flood, 1996, p. 130). This goat scene is the first menace of mimicry, the second one and the most rebellious one takes place when Raja is rented out to perform in a film in which Madan, the director, demands him to appear in his natural self without actually being so. 
From the perspective of traditional Indian reading, the film is a complete fabrication and points how the director, along with Captain, lives such a fantasy world of maya (illusion) that in which man believes himself all important. However, both the circus and the film setting reveal the important distinction between having control over in one's life or not. Yet, it is necessary to look inwardly in determining the best respond to the events in life. Of course, reading this as dharma is deceptive. Although Raja admits that he is well kept by Captain and that he does his best to make himself happier, he says "I was still a prisoner" (Narayan, 1984, p. 96). It is in general impossible to drive a tiger from its nature, and by doing the opposite Captain pushes Raja too his extreme, resulting in what his essential nature requires: killing.

If I could have spoken, I would have told him, 'Go away before any harm befalls you, my good man. After all you have fed me and protected me. I shall honour you for it. But please go away and leave me alone. I won't be your slave any more, I'll never go back to my cage; that's all, I won't do any of the meaningless turns these foolish men around want me to do. [...] I like this air and freedom. I'm not going to give it up now. [...] 'Oh, Captain, don't be foolhardy, your life is in danger, go away, leave me before any calamity befalls you.' But he was drunk with authority. [...] I caught myself thinking, 'Why should I fear this creature no bigger than my tail?' First time in my life such an idea was occurring. So far I had never measured him. In recognition of our relationship and as a final warning I growled and just raised my paw. [...] tore off his head. (Narayan, 1984, p. 99-100)

After the scene in which Raja begins to act as a wild tiger, there is the possibility of pointing the doctrines/ teachings of Hinduism. It addresses to the nature of the human personality that can be deceived and also can overcome such deceptions finally. This also implies the anti-colonial behaviours of Indians and their partition from British rule. When Raja says; "I was enjoying my freedom, and the happy feeling that the whip along with the hand that held it was banished forever. No more of it; it was pleasant to brood over this good fortune" (Narayan, 1984, p. 143), readers trace the development of both spiritual and colonial transformation of Raja and of Indians as well. Freedom calls back happiness which is the feeling of being himself. This is important because it leads to unconditional freedom released from selfdelusion. However this happiness of freedom is ephemeral for Raja. The infinite happiness and freedom comes when Raja masters his nature, his position and his tie with God. 
In this part of Raja's life, Narayan gives the message related with the law of karma that focuses on the compulsory process of human being to reach spiritual awareness and to achieve samàdhi, enlightenment of "I-am-ness" (1984, p. 177). Achieving samadhi is realizing how to behave and to act without being chained since "no relationship, human or other, or association of any kind could last forever. Separation is the law of life right from the mother's womb" (Narayan, 1984, p. 174). These are in fact the teachings of dharma/karma theme which is dominant in Hindu spirituality:

One has to face the reaction of every act, if not in the same life, at least in another life or series of lives. There can be no escape from it. Now you have a chance to realize how your prisoners must have felt in those days, when you locked them in and watched them day by day to measure how far you had succeeded in breaking their spirits. (Narayan, 1984, p. 42-3).

Raja's freedom can be associated with the freedom of educated and enlightened Indians. Through Raja's example, Narayan wants to imply those who are educated could be free, not a dependent of power. This independence of Indians can only be achieved by following the traditions and their own spiritual doctrines. Narayan draws an important line in his novel through the quest of Raja. He illustrates how someone loses his or her identity if there is a copying of power. It is because he shows a sadhu, an Indian spiritual master for salvation, but again he does this critically. Narayan "remains within his tradition but does critically, rejecting the idea of a pure unalloyed tradition and embracing the contradictions of his own position as a mark of creative potential, not of a cultural decline or of a continuing colonial domination" (Ashcroft et al, 2009, p. 118). Narayan draws a path to independence for Indians including children as well as adults with a successful fable. By using tiger which is the most glorious animal of the animal kingdom and India, he makes an implied association with the culture and community. With the wrong or mimicked behaviours of Raja, Narayan shows the colonized panorama of Indian. With the confessions of Raja, he illustrates the slaved and colonized Indians by imperial forces: "Stepping into human society was a thoughtless act. Instead of living the rest of my life majestically as an honest-to-god tiger going in and out of his cave, eating and sleeping, performing no act except what he wished, [...] I had let myself in for 
ultimate slavery. [...] I was mistaken (Narayan, 1984, p. 26). It is Narayan's skill to lead Indians, especially educated ones, to the idea that bears the message an Indian can live freely in a world directed by power. His main goal in this novel is his main message to his own community; to live a life in which traditional doctrines and colonial practices are balanced.

\section{Notes on the contributors}

Reyhan Özer Taniyan (Ph.D.) was affiliated to Niğde Ömer Halisdemir University when this article was authored. She is currently an assistant professor in the Department of English Language and Literature at Pamukkale University, Denizli, Turkey. She researches on English literatures, postcolonial criticism, contemporary novels, gender studies and literary criticism.

\section{References}

Ashcroft, B., Griffiths, G., \& Tiffin, H. (2007). Post-colonial studies: The key concepts. London: Routledge.

Ashcroft, B., Griffiths, G., \& Tiffin, H. (2009). The empire writes back: Theory and practice in post-colonial literatures ( $2^{\text {nd }}$ Ed.). London: Routledge.

Bhabha, H. (1984). Of mimicry and man: The ambivalence of colonial discourse. Discipleship: A Special Issue on Psychoanalysis, 28(2), 125-133.

Bhabha, H. (1994). Remembering Fanon: Self, psyche and the colonial condition. In P. Williams \& L. Chrisman (Eds), Colonial discourse and post-colonial theory: A reader. (pp. 112-123). London: Routledge.

Bush, B. (2006). Imperialism and postcolonialism. London: Routledge.

Chennakesavan, S. (1976). Concepts of Indian philosophy. Madras: Orient Longman.

Childs, P. \& Williams P. (2014). Introduction to post-colonial theory. London: Routledge.

Cohn, B. S. (1996). Colonialism and its forms of knowledge: The British in India. NJ: Princeton University Press.

Firth, S. (1997). Dying, death and bereavement in a British Hindu community. Leuven: Peeters.

Flood, G. (1996). An introduction to Hinduism. Cambridge: Cambridge University Press.

Johnson, R. (2002). British imperialism. Basingstoke: Palgrave Macmillan.

Juergensmeyer, M. \& Roof, W. C. (2011). Encyclopedia of global religion. N.Y: Sage Publications.

Macaulay, T.B. (1903). Critical and historical essays. London: Methuen.

Maehle, G. (2007). Ashtanga yoga: Practice and philosophy. Novato: New World Library.

Narayan, R. K. (1984). A tiger for Malgudi. London: Penguin Books. 
Parry, B. (1987). Problems in current theories of colonial discourse. Oxford Literary Review, 9(1), 27-58.

Riemenschneider, D. (2005). The Indian novel in English: Its critical discourse 19342004. Jaipur: Rawat Publications.

Walsh, W. (1971). R.K. Narayan. London: Longman. 